\title{
IMPACT OF TRACE METALS ON THE DISTRIBUTION OF PHYTOPLANKTON AND THEIR CONTENT IN OREOCHROMIS NILOTICUS AT ROSETTA BRANCH \\ (EGYPT).
}

\author{
Adel H. Konsowa \\ National Institute of Oceanography and Fisheries
}

Key words : Trace metals, phytoplankton, Orcachromis, Roseta Branch .

\begin{abstract}
$T^{\text {he data indicated that El-Rahawy, Sobel, Kafr El-Ziat and Edrina }}$ 1 sectors represent the highly polluted area along Rosetta Stream. Phytoplankton crops recorded downstream the discharging point of El-Rahawy and Kafr El-Ziat Drains were higher than the corresponding values occurred at the upstream areas. At Edfina sector, the numerical density of phytoplankton was high upstream the barrage compared to its downstream sector (Estuarinc) and this phenomenon can be related to the negative impact of high salinity. Bacillariophyceae occupied the first predominant position followed by Chlorophyceae and Cyanophyceae. Diatoms, Green and Bluegreen algae constituted about $99 \%$ of the total phytoplankton crop. Trace metal contents of Rosetta Branch can be arranged in descending order as follows: $\mathrm{Fe}>\mathrm{Mn}>\mathrm{Ni}>\mathrm{Pb}>\mathrm{Co}>\mathrm{Zn}>\mathrm{Cd}>$ $\mathrm{Cu}>\mathrm{Hg}$. The levels of $\mathrm{Fe}, \mathrm{Mn}$ and $\mathrm{Ni}$ in Oreochromis niloticus flesh collected from El-Rahawy, Sobel, Kafr el-Ziat and Edfina were high compared to the samples caught from El-Kanater Sector.
\end{abstract}

\section{INTRODUCTION}

Rosetta Branch serves as a fishing ground for commercial fisheries. It is considered also the main source of freshwater for the western side of Nile Delta. Rosetta Stream receives domestic, industrial and agricultural wastes from several sources that discharge directly or indirectly in the branch. The major sources of pollution to this branch are El-Rahawy (raw sewage) and Sobel (agriculture wastes) Drains, . In the meantime, Soda \& Lime and El-Malya Companies at Kafr El-Ziat City are the main source of industrial pollution to the branch. Trace metals play a significant role in phytoplankton ecology (Barber and Ryther, 1969). Bruland (1980) 
studied the effect of Zinc, Manganese and Iron on the reproductive rate of 21 species of marine phytoplankton. Sunda et al. (1981) investigated the concentration of copper on the oceanic phytoplankton uptake and regeneration cycles. Hickel and Pollingher (1988) studied the structure of the Blue-Green Cyanodictyon imperfectum, showing external Iron deposition between the cells. Kobbia et al. (1993) studied the phytoplankton biomass in the Nile Water near the Starch and Glucose Factory at Giza (Egypt). Massoud et al. (1994) investigated the role of phytopiankton cells on the control of heavy metal concentrations in seawater. Hassan (1996) studied the effect of industrial waste of Iron and Steel Factories on growth, chlorophyll and photosynthetic activity of Scenedesmus quadricauda. Sobhy (1999) investigated the effect of the same waste on natural phytoplankton communities. Hornuny and Krom (1989) determined trace metals in offshore and inshore fish farm from the Mediterranean Sea. Lasheen (1981) determined trace metals of River Nile Water such as $\mathrm{Cd}, \mathrm{Co}, \mathrm{Cu}, \mathrm{Cr}, \mathrm{Pb}, \mathrm{Zn}$ and $\mathrm{Mn}$. Awad (1993) found that the metallic ion concentrations in River Nile water were arranged as follows: $\mathrm{Fe}>\mathrm{Mn}>\mathrm{Zn}>\mathrm{Cu}$

The present investigation was carried out in order to provide information about the effect of pollution on phytoplankton communities in Rosetta Branch and to determine the level of some trace metals in Oreochromis niloticus flesh inhabiting this branch.

\section{MATERIALS AND METHODS}

Four quarterly cruises along Rosetta Branch were carried out in July \& October 1999 and January \& April 2000. The studied area extended from El-Kanater El-Khairya to Edfina Barrage with a total length of $200 \mathrm{~km}$. Eight different sectors were chosen to represent different habitat of this branch. The selected sectors (Fig. 1) were as follows:

- Sector 1 (El-Kanater): situated at about $500 \mathrm{~m}$ downstream El-Kanater ElKhairya Barrage.

- Sector 2 (El-Rahawy): located at about $250 \mathrm{~m}$ downstream the discharging area of the raw sewage.

- Sector 3 (Tamelay): located at about $60 \mathrm{~km}$ from El-Kanater ElKhairya Barrage.

- Sector 4 (Sobel): located at about $250 \mathrm{~m}$ downstream of Sobel Drain. 
- Sector 5 (Kom-Hamada): situated at about $100 \mathrm{~km}$ from El-Kanater El-Khairya Barrage.

- Sector 6 (Kafr El-Ziat): located at about $250 \mathrm{~m}$ downstream the industrial waste of Soda \& Lime and Malya Companies.

- Sector 7(Edfina 1): located at about $250 \mathrm{~m}$ upstream Edfina Barrage. - Sector8(Edfina2):located at about250m downstream Edfina Barrage.

Composite water samples were collected by Ruttner Bottle to represent the middle and the two banks of each sector. Sedimentation method was used to concentrate of phytoplankton cells. Drop method technique was applied for counting the phytoplankton community (APHA, 1992).

For trace metal analyses, subsamples werc fixed with concentrated $\mathrm{HNO}_{3}$ to $\mathrm{pH}<2$. Mercury was determined in the water by preservation in situ with $5 \% \mathrm{KMnO}_{4}$ to violet color and measured by cold vapor technique, using Hydride Unit Model (MAS-10). 0 . niloticus were collected from various sections of the branch. A known weight from its dried flesh was digested in concentrated $\mathrm{HNO}_{3}$ according to APHA (1992). Determinations of trace metal concentrations in water and flesh were carried out by Atomic Absorption Perkin Elmer Model (3110) according to APHA, (1992).

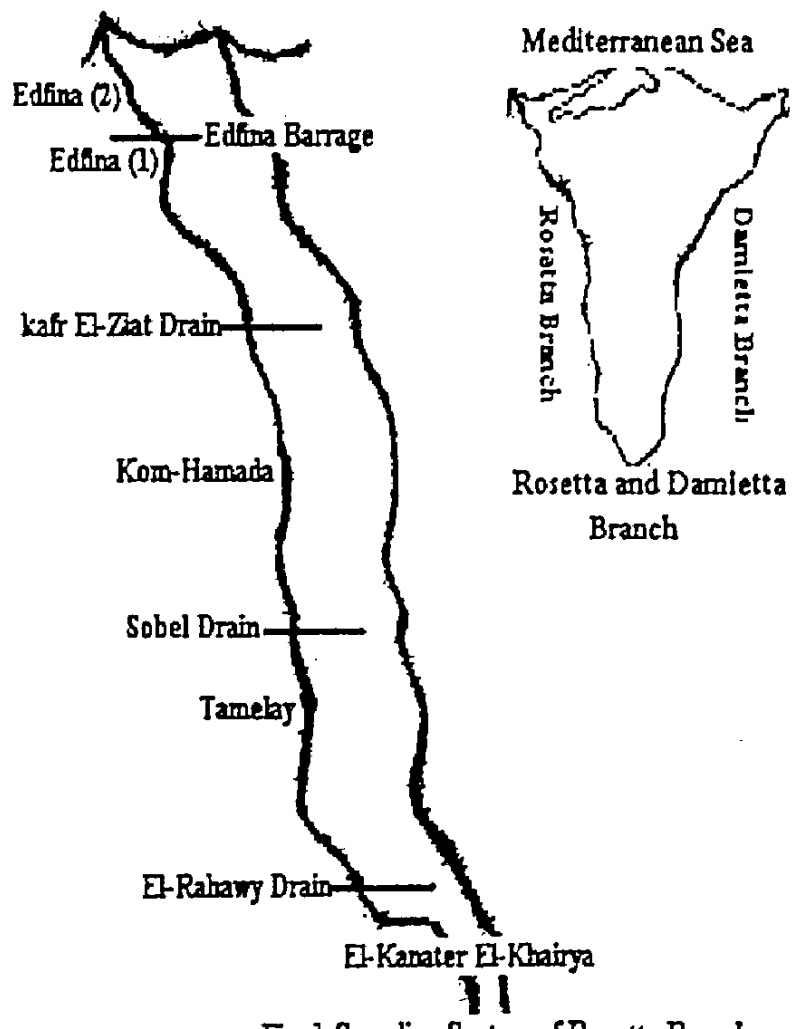

Fig. 1-Sampling Sectors of Rosetta Brmeh 


\section{Results}

The present results (Table 1) indicated that the downstream of El-Rahawy, Sobel and Kafr El-Ziat Sectors harbored high phytoplankton crops compared to their upstream areas. Phytoplankton community at Edfina (2) showed a sharp decline downstream Edfina Barage (Rosetta Estuarine) compared with Edfina(1) The phytoplankton inhabiting Rosetta Branch were represented by five classes namely, Bacillariophyceae, Chlorophyceae, Cyanophyceae, Euglenophyceae and Dinophyceae as shown in Table (2). Diatoms occupied the first predominant position, constituting $63.27 \%$ of the total phytoplankton crop. Their maximum count was recorded at ElRahawy, while the minimum number was found at Edfina (2). The leading species of diatoms, green and blue-green algae are given in Table (3) and can be summerized as follows: Diatoms were dominated by Melosira granulata, Synedra ulna, Cyclotella chaetoceras and Cyclotella ocellata.

Melosira granulata was the most abundant species. Synedra ulna and Cyclotella ocellata were observed at all sections except Edfina (2). Cyclotella chaetoceras decreased gradually from ElKanater to Sobel and completely disappeared at Kom-Hamada, Kafr El-Ziat and Edfina Sectors. Chlorophyceae were less found compared with diatoms. They occupied the second predominant position, contributing $27 \%$ of the total phytoplankton crop. Their numerical density showed an obvious increase at Sobel and Kafr-El-Ziat and were dominated by Oocystis parva, Ankistrdesmus falcatus, Scenedesmus quadricauda and Pediastrum simplex. Cyanophyceae occupied the third predominant position and constituted $8.8 \%$ of the total phytoplankton crop. Blue-greens were dominated by Microcystis aeruginosa and Cylindrospermopsis raciborskii, Lyngbya limmnetica and Merismopedia tenuissima. Euglenophyceae and Dinophyceae were scarce and represented only by Euglena varibilis, Phacus pleuronectes and Peridinium cinctum.

Trace metal concentrations in the water can be arranged as follows: $\mathrm{Fe}>\mathrm{Mn}>\mathrm{Ni}>\mathrm{Pb}>\mathrm{Co}>\mathrm{Zn}>\mathrm{Cd}>\mathrm{Cu}>\mathrm{Hg}$. Their concentrations are shown in Table (4\&5) and can be summerized as follows:

Iron concentrations ranged from $2.2 \mathrm{ppm}$ at Edfina (1) in summer to $238.7 \mathrm{ppm}$ at Edfina (2) in spring. Manganese levels fluctuated between $0.8 \mathrm{ppm}$ at El-Kanater in autumn and $33.6 \mathrm{ppm}$ at Edfina (2) in summer. Nickel minimum value of $0.2 \mathrm{ppm}$ was 
recorded at Tamelay in summer, while its maximum concentration of $29.2 \mathrm{ppm}$ occurred at El-Rahawy in autumn. Lead concentrations varied from $0.2 \mathrm{ppm}$ at El-Kanater in summer to $28.2 \mathrm{ppm}$ at Edfina (2) in spring; Cobalt minimum value of $0.2 \mathrm{ppn}$ was determined at El-Kanater in summer, while its maximum concentration of $9.6 \mathrm{ppm}$ occurred at Edfina (2) in autumn. Zinc concentration increased from $0.2 \mathrm{ppm}$ at El-Kanater in winter to $21.2 \mathrm{ppm}$ at Kafr El-Ziat in autumn. Cadmium values ranged from $0.1 \mathrm{ppm}$ at El-Kanater in winter to $4.8 \mathrm{ppm}$ at Edfina (2) in summer. Copper content was below the detection limits at El-Rahawy, Tamelay, Sobel and Edfina (1) \& (2) while its maximum level of $3.41 \mathrm{ppm}$ was detected at Kafr El-Ziat in autumn. Mercury concentrations were substantially low compared to the other trace metals determined in Rosetta Branch. Its concentrations ranged from $0.003 \mathrm{ppm}$ at Kom-Hamada in summer to $0.17 \mathrm{ppm}$ at El-Kanater in winter.

Trace metal concentrations measured in flesh of $O$. niloticus (Table 6) showed that iron content was much higher than manganese and nickel concentrations measured at the selected fish. In the same time; Iron levels at El-Rahawy Sector had a substantial increase in comparison with the other polluted sectors at Sobel, Kafr El-Ziat and Edfina (2).

\section{DISCUSSION}

It is evident from the data that the population density of Cyclotella chaetoceras, Melosira granulata, Cyclotella ocellata and Synedra uIna at El-Rahawy and Kafr-El-Ziat were abnormally higher than the other sectors. This can be realized to stimulatory effect of wastes that are discharged at these areas. This agrees witi. Sobhy (1999) who recorded high densities of diatoms at the highly polluted area at Helwan. He reported that this area is polluted by Fe (120 $\mathrm{ppm}), \mathrm{Zn}(25.4 \mathrm{ppm})$ and $\mathrm{Mn}(20 \mathrm{ppm})$.

In spite of the high concentrations of $\mathrm{Fe}(63.45 \mathrm{ppm})$ and $\mathrm{Mn}$ (12 ppm) at Sobel, green algae were flourished and dominated by Oocystis parva, Ankistrodesmus falcatus, Scenedesmus quadricuda, Pediastrum simplex and Golenkinia radiata. This finding can be related to the high nutrient levels (N\&P) in the agricultural drainage waters that are discharged via Sobel Drain. In this respect, Flores \& Barone (2000) stated that different algal species can exploit nutrient 
sources, both organic and inorganic, with varying capabilities. They also found that different nitrogen sources may selectively stimulate the development of dominant algal species. In general, Chlorophyta was represented by less species number at polluted area of River Nile (Starch and Glucose Factory), yet its percentage composition was maximum and ranged from 67 to $93 \%$ of the total yield (Kobbia et al. (1993).

The blue-green algal species Micrcystis aeruginosa, Merisopedia tenuissima and Cylindrospermopsis raciborskii had increased at the downstream of the industrial waste at Kafr El-Ziat City. This revealed the tolerance of these species to the industrial waste pollution. In this respect, Cranodictyon \& Weibull (1981) reported that the blue-green Cyanodictyon imperfectum is characterized by the ability to precipitate iron oxide, which is deposited externally in the mucilage between two adjoining cells in the form of dense rings. Davila (1995) found that numerous species of algae bind metal ions with protein or polysaccharides in the interior of the cell, which may deactivate the metal ion's toxicity.

Dinoflagellates were rarely found along Rosetta Branch except Sobel Sector, where Euglena varibilis, Phacus pleuronectes and Peridinium cinctum occurred. This observation may be attributed to drainage water that was loaded with agricultural wastes, especially nitrogen and phosphorous compounds. This agrees with $\mathrm{Abd} \mathrm{El}$ Karim (1999) who pointed out that dinoflagellates flourished at Damietta Branch towards the downstream of Faraskour Sector due to the high nutrient concentrations.

Phytoplankton standing crop and species composition at Edfina (2) showed a sharp decline compared to Edffina (1). Most of phytoplankton species recorded at this branch are completely freshwater. Therefore, the abnormal increase of salinity ( $9 \mathrm{ppt}$ ) recorded at the beginning of Rosetta Estuarine has adverse effect on phytoplankton crop. Generaliy, the toxic effect of salinity on phytoplankton might be due, at least in part, to its interference with the uptake of magnesium by the growing organisms (Tempest $\&$ Meers, 1968).

The high trace element concentrations in $O$. niloticus flesh is mainly related to their high levels in the water, especially in the polluted sectors. The accumulation of metallic ions in its flesh is mainly through their natural food (phyto \& zooplankton). These data agree with the findings of Mathis and Cummings (1993) who reported that the concentration of trace metals in the omnivorous fish muscles 
in the Illinois River was appreciably greater than that in the muscles of carnivorous fish. The trace metal concentrations in the surface water of Rosetta Branch are exceeding the permissible levels that recommended by Egypt Environmental Affairs Agency (EEAA, 1994) except Zinc. The permissible level of trace metals in surface water reported by EEAA, 1994 are as follows: Fe, $1.5 \mathrm{ppm}$; Mn, 1.0 ppm; Ni, 0.1 ppm; Pb, 0.5 ppm; Co, 2 ppm; Zn, 5 ppm; Cd, 0.05 ppm; $\mathrm{Cu}, 0.5 \mathrm{ppm}$ and $\mathrm{Hg}, 0.005 \mathrm{ppm}$

The metallic ion levels in $O$. niloticus flesh caught from Rosetta Branch have adverse effects on human health. So it is recommended to solve the pollution prob.ems in Rosetta Branch by treating all the wastes (sewage, industrial and agricuiture effluents) before their discharge to the natural water.

\section{REFERENCES}

Apha (American Public Health Association), (1992)."Standard method for the examination of water and wastewater", 18 th A.P.H.A. AWWA. WPCF. American Public Health Association 1015 pp.15 th St. N.W.Washington D.C 20005.

Abd El-karim, M.S. (1999). Phytoplankton dynamic and its productivity in Damietta Branch. Ph.D thesis, Botany Dep. Fac. Girls, Ain Shams Univ., 193 pp.

Awad, F.K.(1993). Distribution of some trace element in the River Nile from Esna to El-Kanater El-Khyria, Egypt. M.Sc. Thesis, Chem. Dep., Fac. Sci., Alex. Univ., 223 pp.

Barber, R.T. and Ryther,J.H(1969).Organic chelators; factors affecting primary production in the Cromwell Current upwelling J. Exp. Mar. Biol. Ecol., 3: 191-199.

Bruland, K.W. (1980). Oceanogtaphic distribution of Cadmium, Zinc, Nickel and Copper in the North Pacific Earth Planet. Sci. Lett., $47: 176-198$. 
Cranberg G.\&Weibull C.(1981). Cynodictyon imperfectum a new chroococcal blue-green alga from lake Trummen, Sweden. Arch. Hydrobiol. Supp.60 (Algal. Stud., 27): 101-110

Davila, M. G. (1995). The role of phytoplankton cells on the control of heavy metal concentration in seawater. Mar Chem., 48: 215-236.

Descy, J.P. (1993). Ecology of the phytoplankton of the River Moselle: Effect of disturbances on community structure and diversity. Hydrobiol., 289:11-116.

Flores, L.N. and Barone, R. (2000). Phytoplankton dynamics and structure: a comparitive analysis in natural and man-made water bodies of different trophic state. Hydrobiol., 438: $65-74$.

Hassan, H.T. (1996). Ecological studies on the Nile River phytoplankton inrelation to physico-chemical characteristics at the area between Esna and Delta Barrage. Ph.D. Thesis, Bot. Dept., Fac. Girls, Ain Shms University, $203 \mathrm{pp}$.

Hickel, B. and Pollingher,U.(1988).Mass development of an Iron precipitating Cyanophyta (Cyanodictyon imperfectum) in a subtropical lake (Lake Kinneret). Phycologia.,27(2):291-297.

Hormung, H. and Krom, M.D. (1989). Study of heavy metal levels in sediments, benthic fauna and some fishes from the Mediterranean Sea. IOLR. Rep., H 11/89.

Ibrahim, E.A. (1981). Investigation of level and effect of pollutants on saline lakes and littoral marine environments, Academy of Scientific Research and Technology, Technical Report., No. 11:165 pp.

Kobbia, I.A., Dowidar, A.E. and Shabana, E.F. (1993). Succession, biomass levels of phytoplankton in the Nile water near the Starch and Glucose Factory at Giza (Egypt). Egypt I. Microiol., 28(1):131-143. 
Lasheen, M.A. (1981). Distribution pattern of selected trace metals in Aswan High Dam Reservoir. Bull. Nat. Ress. Cent. Egypt.. $6: 457-474$.

Massoud, M.S., Elewa, A.A. and Awad, F.K. (1994). Distribution of some trace metals in River Nile waters. Bull. Fac. Sci., Assiut Univ., $23(1-b)$ : 67-82.

Mathis, B.J., and Cummings, T.F. (1973). Selected metals in sediments, water and biota in the Illinois River. J. Wat. Pollut. Control Fed., 45 (7): 1573-1583.

Olive, J.H. (1995). Diatom communities in Cuyahoga River (USA): Changes in species composition between 1974 and 1992 follow in renovations in wastewater management. Ohio J.Sci., 95 (3): 254-260.

Shabin Dessouk.,S.A. and Baka,Z.A. (1985). Dynamics of phytoplankton abundance, chlorophyll content and their population diversity in Damietta Branch of the River Nile. Bull. Fac. Sci. Mansoura Uniy., $12: 49-84$.

Sobhy, E.M. (1999). Effect of industrial waste of Iron and Stecl Factories on Nile phytoplankton communities and productivity at Helawan. Ph.D Thesis, Botany Dept. Fac. of Girls, Ain Shams Univ., $231 \mathrm{pp}$.

Sunda, W.G., Barber, R.T. and Huntsman, S.A. (1981). Phytoplankton growth in nutrient rich seawater; importance of coppermanganese cellular interactions. J. Mar. Res., 39 : 567-586.

Tempest D.W. and Meers. J.L. (1968). The influence of sodium chloride concentration of the medium on the potassium content of Aerobacter aerogenes and on the inter-relationships between potassium, magnesium and ribonuclic acid in the growing bacteria. J. Gen. Microbiol., 59 : 319-328.

Wu, J.T.R., and Suen, W.C. (1985). Change of total associations in relation to water pollution. Bot. Bull. Acad. Sci. (Taipei).,26(2):203 





IMPACT OF TRACE METALS ON THE DISTRUSUTION OF 247
PHYTOPLANKTON AND THEIR CONTENT IN OREOCHROMIS
NILOTICUS AT ROSETTA BRANCH

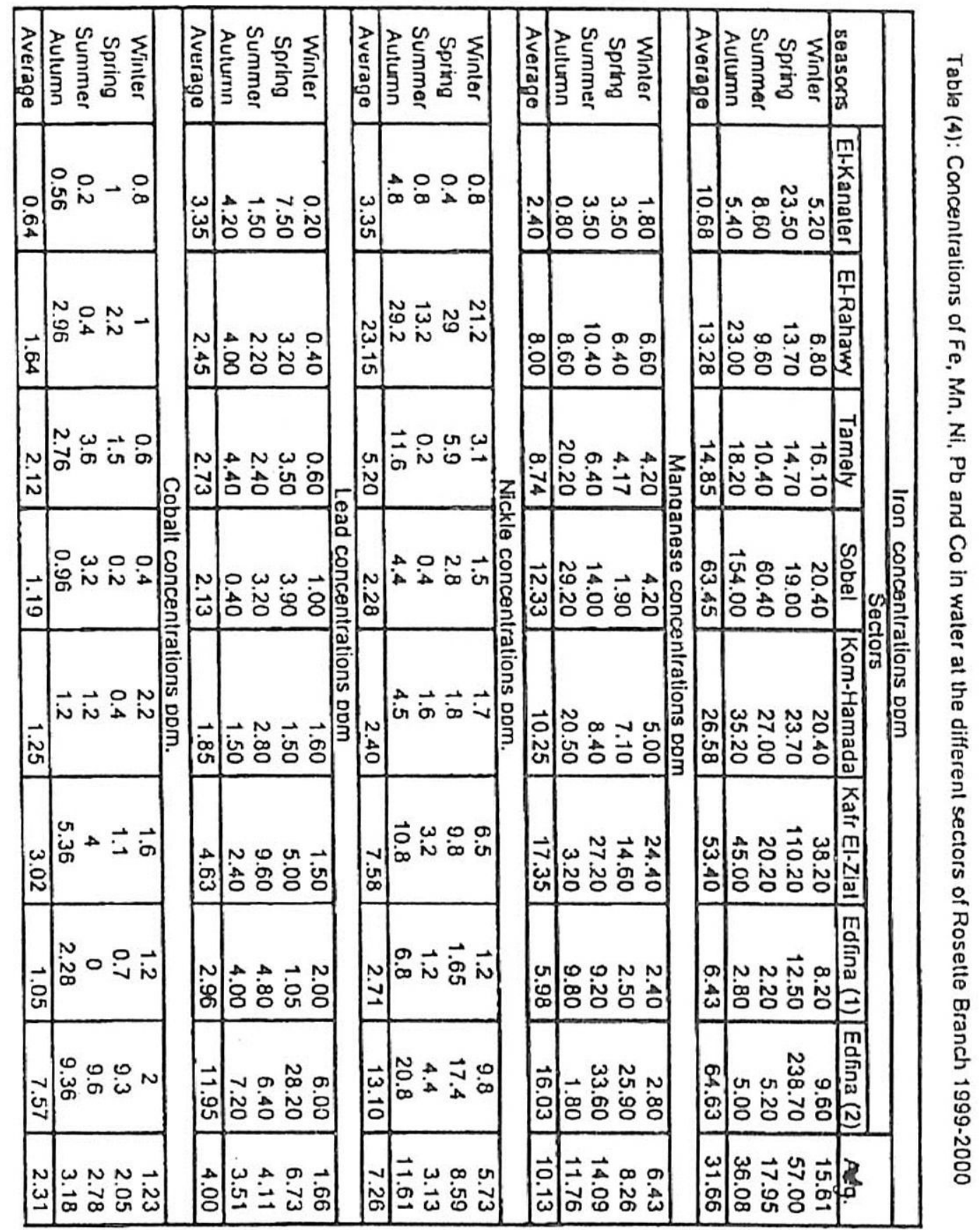




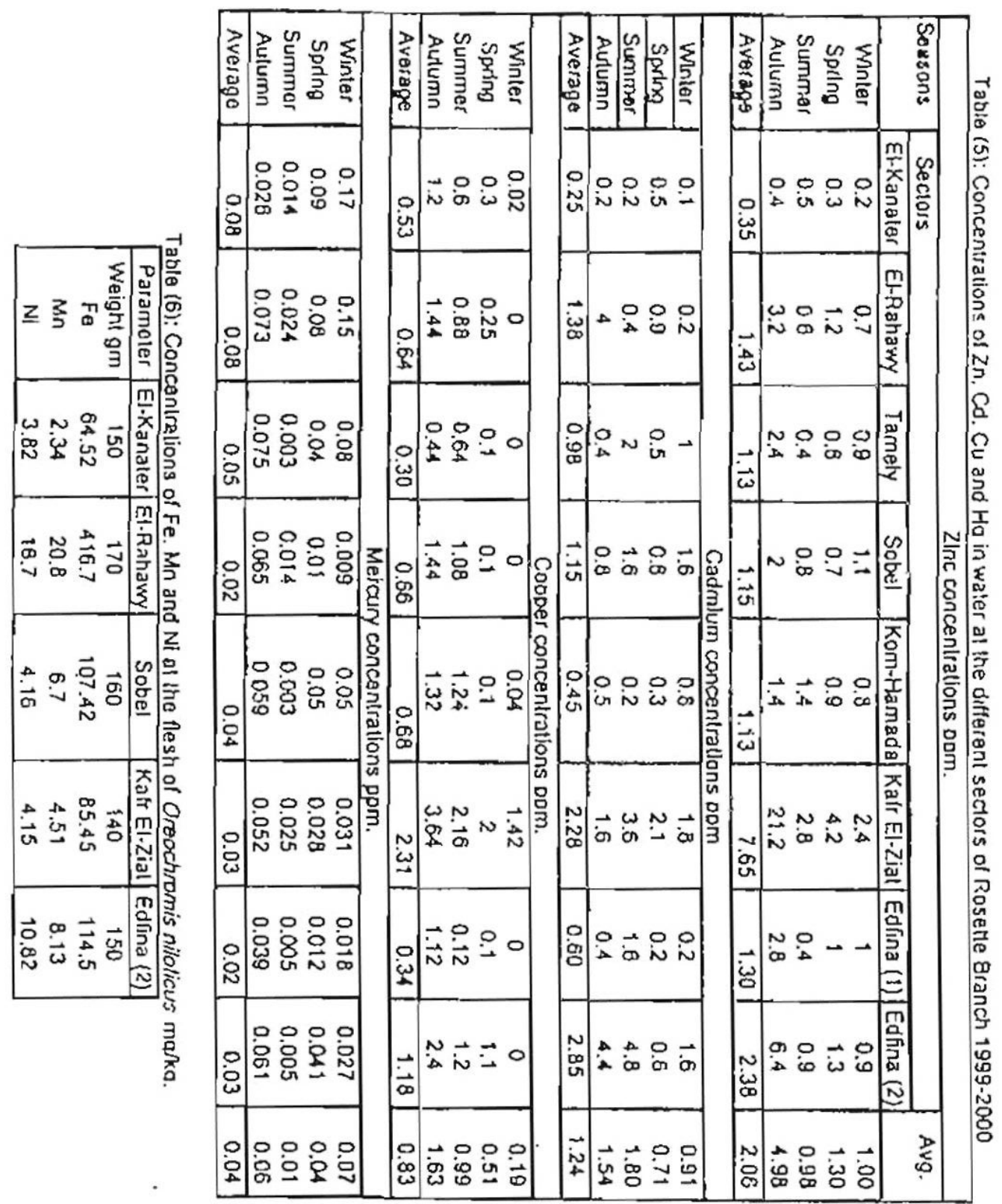

